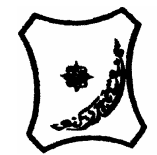

Bayero Journal of Pure and Applied Sciences, 2(1): 109 - 114

Received: March, 2009

Accepted: May, 2009

\title{
AN OVERVIEW ON THE APPLICATION OF POLYMERASE CHAIN REACTION (PCR) IN THE DIAGNOSIS OF BACTERIAL INFECTIONS
}

\author{
*Usman, A.D. and Ali, S. \\ Department of Biological Sciences, Bayero university, P.M.B. Kano \\ *Correspondence author
}

\begin{abstract}
This overview describes the principle of polymerase chain reaction as one of the most important techniques used in the diagnosis of bacterial infections due to its reliability, sensitivity and rapidness. It also identifies some of the limitations of the technique as well as some of the bacterial infections that can be diagnosed using the technique which include among others; Tuberculosis (TB), whooping cough, brain abscesses and spinal infection, otitis media with effusion, Mycoplasmal pneumonia, endophthalmitis and bacterial meningitis.
\end{abstract}

Keywords: Polymerase chain reaction, Diagnosis, Bacteria, Infections

\section{INTRODUCTION}

The polymerase chain reaction (PCR) is a technique widely used in Molecular biology. It derives its name from one of its key components, DNA polymerase used to amplify a piece of DNA by in-vitro enzymatic replication (David and Turlotte 1998). As PCR progresses the DNA generated is used as a template for replication. This sets in motion a chain reaction in which the DNA template is exponentially amplified. With PCR, it is possible to amplify a single or few copies of DNA across several orders of magnitude, generating millions for more copies of the DNA piece (Rhoads et al., 1990). Developed in 1984 by Kary Mullis (Barlett and Stirling, 2008), PCR is now a common and often indispensable technique used in medical and biological research labs for a variety of application (Saiki, et al, 1988). These include DNA cloning for sequencing, DNA based phylogeny, or functional analysis of genes; the diagnosis of hereditary diseases; the identification of genetic finger prints (used in forensic sciences and paternity testing); and the detection and diagnosis of infectious diseases (Saiki, et al 1998). In 1993 Mullis was awarded the Nobel Prize in chemistry for his work on PCR (Karry, 1993).

Kleppe et al, (1971) first described a method using an enzymatic assay to replicate a short DNA template with primers in vitro. However, this early manifestation of the basic PCR principle did not receive much attention, and the invention of the polymerase chain reaction in 1983 is generally credited to Karry Mullis (Rabinow and Paul, 1996).
The polymerase chain reaction (PCR) uses a thermostable DNA polymerase, 2 synthetic oligonucleotide primers and the 4 standard deoxyribonucleosides found in DNA to produce multiple copies of specific nucleic acid regions quickly and exponentially, including non-coding regions of DNA as well as particular genes (Erlich, 1989).

Each PCR amplification consists of 3 steps that are repeated in cycles. These are:

1. Strand separation (denaturing) of the double stranded sample DNA at $94^{\circ} \mathrm{C}$.

2. Hybridization (annealing) of the 2 primers to opposite DNA strands at $65^{\circ} \mathrm{C}$.

3. Extension of the primers by polymerase mediated nucleotide additions to produce 2 copies of the original sequence at $72^{\circ} \mathrm{C}$.

The repeated cycles result in an exponential reaction in which the original target sequence is amplified a million fold or more within a few hours (Erlich, 1989). The visualization of a specific amplification product by electrophoresis on an agarose or polyacrylamide gel is often sufficiently diagnostic for most amplification purposes, but PCR amplification is sometimes combined with a hybridization assay to confirm the specificity of the reaction (Erlich, 1989).

\section{Objectives of the Study}

- To review how the principle of PCR is applied in the diagnosis of bacterial infections.

- To review the various PCR techniques employed to diagnose various bacterial infections. 
Limitation of PCR in the diagnosis of bacterial infections

Apart from the need for specific primers to direct the amplification reaction, the main problem with the use of PCR is identifying bacteria for diagnostic purposes from the exquisite sensitivity of the technique. Since even a single molecule of target DNA can, in theory, be amplified to give a positive reaction, the slightest contamination of glassware, pipettes or reagents can result in the production of false positive results unless appropriate stringent laboratory procedures are followed carefully (Earlich et al., 1989). As an additional consequence, quantification of the number of specific bacteria in a sample is not possible, and it is also important to remember that technique will detect dead as well as viable bacterial cells (Innis and Gelfand, 1990).

Quite simply, the PCR enables the rapid synthesis of many, many copies of a specific DNA fragment from a complex mixture of DNA. Researchers can thus obtain large quantities of specific pieces of DNA for experimental and diagnostic purposes (Cockerill and Smith 2002). However, the main objective of PCR is to detect the presence of bacteria in a sample that might be negative in a routine culture and serology due to their very little or trace quantity in a sample or as a result of antimicrobial administration.

Direct amplification of rRNA genes in the diagnosis of bacterial infection

The rRNA molecules typically consist of highly conserved sequences interspersed with regions of more variable sequences (Gutel et al., 1985). Together with the development of the PCR technique, this knowledge has provided an approach for recognition of bacterial pathogens (Mullis and Falcoona 1987). Subsequently, broad range bacterial PCR has been used to amplify bacterial genes directly from clinical samples, e.g. biopsy specimens from diseased tissue, with the aim of establishing etiologic diagnoses of various bacterial diseases in a clinical setting. These earlier studies have involved a limited number of specimens and have focused on one defined bacterial diseases only e.g. endocarditis, intra-amniotic infection, meningitis, bacteremia and hepatitis (Knox et al; 1998).

PCR in the Diagnosis of Tuberculosis (TB)

Tuberculosis is a major cause of morbidity and mortality throughout the world in both industrialized and developing countries inspite of the availability of antitubercular therapy (ATT) for many years. In 1990, an estimated 8 million people developed TB worldwide with 2.6 to 2.9 million deaths. The majority of these cases occur in Asia and Africa with an increasing number among HIV infected individuals (Sudre et al; 1992).

Sunil et al. (2000) conducted a research for the evaluation of the efficacy of polymerase chain reaction (PCR), using the insertion sequence IS6110 as target for DNA, to detect Mycobacterium tuberculosis in body fluids of children suspected of tuberculosis (TB) infections. The result of PCR on body fluids was compared with that of acid fast bacilli (AFB), Mycobacterial culture and clinical features with special emphasis on central nervous system (CNS), over 18 month period. The result revealed that sensitivity of PCR in CSF samples was $100 \%$, in gastric aspirate samples was $20 \%$ and in pleural fluid samples was $100 \%$ which concluded that PCR techniques may become a valuable diagnostic tool for the diagnosis of tuberculosis in children especially in Central Nervous System Tuberculosis (CNSTB) (Sunil, et a/2000).

\section{PCR in the Diagnosis of Brain Abscesses and Spinal Infection by Bacteria}

A brain abscess is a localized pyogenic bacterial infection within the brain parenchyma (Brooks et al 2007). Brain abscess is caused by Mycoplasma hominis and are only identified by PCR. Based on this study, it was found that for patients with brain abscesses and spinal infections, the broad range bacterial rDNA PCR approach may be the only method to provide an aetiological diagnosis when the patient is receiving antimicrobial treatment, or when the causative agents are small to be detected by culture method (Kupila et a/2003).

\section{PCR in the Diagnosis of Mycoplasma Pneumoniae infection in children}

A 1-year prospective study conducted during 2005 in central Jaivan enrolled 307 hospitalized children (aged 3 months to 16 years) with respiratory tract infections, some complicated with systemic manifestations, such as encephalitis and skin rash. PCR analysis of samples using a primer set for the $\mathrm{P} 1$ gene of $M$. pneumoniae was compared with serological testing, including particle agglutinin test and enzymes-linked immunosorbent assay. 
However, based on these comparisons, the PCR method could provide earlier diagnosis of $M$. pneumonial infection and was useful to identify variable clinical features of infection, especially in younger children.

PCR in the Diagnosis of Otitis media with

\section{Otitis media with effusion (OME) is the most common}

Otitis media with effusion (OME) is the most common cause of hearing loss in children and requires antibiotic and surgical management (Rayner et al; 1998). It can lead to adverse effects in speech and language development in children due to hearing disturbances if it persists for a long period of time (Rayner et al; 1998). According to Senturia et al (1958), repeatedly the detected such bacteria as Haemophilus influenzae, Streptococcus pneumonia, and Moraxella catarrhalis from middle ear effusion and were also detected in numerous studies. Chul et al., (2004) conducted a study to investigate polymerase chain reaction based detection of bacterial DNA in middle ear fluid and to assess the correlation between the PCR positive rate with several factors associated with middle ear effusion. The overall detection rate of bacterial DNA using PCR method was $36.7 \%$ for middle ear effusion, and bacterial DNA detection rates of Haemophillus influenzae, Streptococcus pneumoniae, Moraxella catarrhalis in the middle ear effusion were $29.1 \%, 3.7 \%$ and $10.8 \%$ respectively.

\section{PCR in the Diagnosis of Whooping Cough}

According to Lena (1998), PCR using primers p1p1 and p1p2, was evaluated for the detection of DNA from Bordella pertussis in bacterial strains and in nosopharyngeal samples from patient with a cough lasting atleast 7 days. The assay could detect DNA from $6 \mathrm{cfu}$ of $B$. pertussisis in $10 \mathrm{ml}$ of sample. The results of the PCR were compared with those of cultures, determination of serum antibodies against pertussis toxin on filamentous hemagglutin, and clinical evaluation of 2,442 coughing episodes. The overall sensitivity of PCR was $65 \%$ (632 of 956), which was higher than the sensitivity of culture (58\%). The specificity of PCR was 985 (1,451 of 1486). The positive and negative predictive values were 95 and $81 \%$, respectively.

PCR in the Diagnosis of Endopthalmitis infection Endophthalmitis is the inflammation of eye due to infection caused by a large clinical series, Gram- positive bacteria counted $56-90 \%$ of all cases of endophthalmitis. Marek et al (2006), conducted a study with 30 clinical specimen $18 \mathrm{AH}$ and $12 \mathrm{VF}$ from 20 eyes with the clinical diagnosis of endophthalmitis. One convensional microbiological technique (microscopy and diagnostic culture) and 2 PCR direct at 165rDNA using universal primers. Based on these result, Marek et al (2006), concluded that PCR performed on aqueous humor and vitreous fluid is a reliable tool for the diagnosis of causative organism particularly in smear and culture negative specimens.

\section{PCR in the Diagnosis of Bacterial Meningitis}

Acute bacterial meningitis is most frequently caused by the pathogens Neisseria meningitidis and Streptococcus pneumoniae and less frequently by Streptococcus agalactiae, Haemophilus influenzae, Escherichia coli and Listeria monocytogenes among others (Santos, 2007). In recent years, the polymerase chain reaction (PCR) has been used increasingly to detect a broaded range of bacteria including those that most frequently cause meningitis (Welinderolsson, 2007). PCR was used with universal primers and followed by hybridization with specific probes to identify agents causing bacterial meningitis. To assess the sensitivity and specificity of this PCR technique, a multicenter study was coordinated by the general health department (Barcelona, Spain) and carried out in three hospitals in cataloma. (Welinderolsson 2007)

\section{DISCUSSION}

Polymerase chain reaction (PCR) is a valuable technique in the diagnosis of bacterial infection. Molecular methods might be superior to bacterial culture in providing the etiologic diagnosis (Kotilainean et al., 1998). Another advantage of bacterial PCR is connected to its broad-range nature since rare or unexpected pathogen can be found. A comparison to culture results reveals difficulties in detecting gram positive species and Mycobacterium by PCR (Kotilanean et al., 1998). Factors influencing the sensitivity of PCR were the interval between the onset of symptoms and sampling and the vaccination status of the patient (Lena et al., 1998). Amplification of $M$. tuberculosis specific DNA sequence in clinical samples is the most sensitive and rapid method of detecting available bacteria (Hermans et al., 1990). 
False positive results are known to be a problem with PCR technique, both in research and hospital laboratories (Noordhock et al., 1997). The broad, range bacterial rDNA PCR approach may be the only method which provide an etiological diagnosis of brain abscesses and spinal when the patient is receiving antimicrobial therapy which is not in local culture and serology (Kupila et al.; 2003).

PCR methods have been developed over the last decade over the years; various primers have been investigated including the P1 virulence gene (Ferwerda, et al., 1995). The P1 adhesion gene primers have proved more sensitive than the 165RNA primers $\mathrm{n}$ the detection of $M$. Pneumoniae infection (Reznikov et al., 1995).

Some limitations in this regard is that PCR may detect a mild infection, a carrier state (Gnarpe, et al, 1992) or the persistence of $M$. pneumoniae in the respiratory tract after a recent infection (Skakni et al., 1992).

PCR in the diagnosis of whooping cough may have some limited usefulness for an additional three weeks in which the bacteria can be recovered from the patient only during the first three weeks of illness, rendering culturing and FA useless after this period (Rowland and Frey, 2005).

However, the PCR method is useful in the diagnosis of endophthalmitis as the study carried out by Merek, et al, (2006) where PCR was performed on aqueous humor and vitreous fluid is reliable tool for diagnosis of causative organisms particular in smear and culture negative specimens. There is still considerable controversy on whether or not the bacterial DNA detected by PCR implies the existence of metabolically active bacteria because DNA from both living and dead microbial cells could be detected by

\section{REFERENCES}

Barlett and Stirling (2003), A Short History of Polymerase Chain Reaction. In Methods Mol. biol. 226: 3-6: http://en.wikipedia.org/wikiuse.

Brooks, G.F., Karen, C.C, Janets, S.B and Stephen, A.M (2007), Jawetz, Mellnik and Adelbergs Medical Microbiology $24^{\text {th }}$ Edition. McGrawHill New York Pp818.

Chul, W.P., Jang-Hee, H., Jin-Hyeok, J. et al (2004) Detection rates of Bacteria in chronic Otitis the technique. However, in a study using a chinchilla model based on purified genomic DNA or pasteurized bacteria, it has been confirmed that neither were detected in middle ear effusion after 3 days while they were detected for over 21 days in cases where antibiotics were used for treatment (Post, et al, 1995). PCR is also useful in the detection of bacterial meningitis in which the PCR sensitivity and specificity was recorded highest. Followed by hybridization with specific probes were determined in purified DNA for Escherichia coli and Haemophilus influenzae and in normal CSF samples experimentally (Santos, 2007).

\section{CONCLUSION AND RECOMMENDATIONS}

Various types of bacterial infections were diagnosed using PCR techniques, some of the bacterial infections include, Tuberculosis (TB) whooping cough, Brain abscesses and spinal infection, Otitis media with effusion, Mycoplasma penumoniae, Endaphthalmitis and Bacterial meningitis which were compared with other laboratory methods such as culture and serology methods. PCR technique may become a valuable diagnosis tool for the diagnosis of bacterial infection because of the reliability, high sensitivity, specificity and is a rapid technique. Among the laboratory techniques for the diagnosis of bacterial infection, the polymerase chain reaction (PCR) were the best techniques for the diagnosis of Tuberculosis (TB), it is recommended that Government and other agencies concerned should provide the constant supply of electricity, qualitative microscopes and biotechnology equipments like the PCR machines, electrophoretic apparatus, refrigerated centrifuges as well as consumables like primers and polymerases to hospitals and research centres. Seminars and workshops should be organized in order to update knowledge of laboratory workers and research centres on the application of biotechnology in the diagnosis of diseases.

Media with Effusion in Children, Journal of Korean Medical Sciences 19: 735-738.

Cockerill, F.R. and Smith, T.F. (2002). Rapid-Cycle real time PCR: A revolution of clinical Microbiology. ASM News 68:2. In: Jounne M.W; Lind, M.S; and Christopher J.W (2008), Press Cott, Harley and Kleins Microbiology $7^{\text {th }}$ edition. McGraw-Hill New York, Pp.362.

David, F. and Turlotte, E.(1998), "An Isothermal Amplification Method". C.R. Acad. Sci Paris Life Science 32 1(1): 909-914. 
Erlich; H.A. (1989). PCR Technology, Principles and Applications for DNA Amplification. Stockton Press, New York. In: Lesliecs Albert B. and Maxs (1998) Topley and Wilsons Microbiology and Microbial Infections, $9^{\text {th }}$ Edition Volume 2, Oxford University U.S.A Pp.75.

Gnarpe, J., Lundback, A., Sundelof, B. and Gnarpe, H. (1992). Prevalence of Mycoplasma pneumoniae in subjectively healthy individuals. Scandanavican Journal of Infectious Diseases. 24: 161-164.

Gutel, R.R., Weiser, B. Wocse, C.R and Noller. H.F. (1985) Comparative anatomy of 16-s-like ribosomal RNA Prog. Nucleic Acids Res. 32:155 - 216. In: Kaisu, R.J., Simo, N., Jari, J. et al (2000), Direct Amplification of rRNA genes in Diagnosis of bacterial infections. Journal of Clinical Microbiology 38(2) 32-39.

Hermans, P.W.M., Schuitema, A.R.J, Van Soolingen d; et al (1990). Specific detection of Mycobacterium tuberculosis compuse strains by polymerase chain reaction. Journal of Clinical Microbiology 28: 1204-1213. In: http:/www.ncbi.nim.nih.goventerezqueryfcgi?

Innis, M.A. and Gelfand, D.H. (1990). PCR Protocols a Gruide to Methods and Applications, Academic Press, San Diego. In Lestiecs Albert B. and Maxs (1998). Topley and Wilsons Microbiology and Microbial Infectives. $9^{\text {th }}$ Edition Volume 2, Oxford University U.S.A PP75.

Karry, M.(1993). NobelLecture

In:http:enwikipedia.org/wiki/use_of_DNA_in_ foreinsic Entomology.

Kleppe, K., Ohtsuka, E., Kleppe, R; Molineux, I., and Khorana, H.E. (1971). "Studies on polynucleutides. XCVI Repair replication of short synthetic DNA's as catalyzed DNA polymerase" Journal of Molecular Biology. 56: 341-361. http://www.sciencedirect.comscience?

Knox, C.M., Cevellos, V. and Dean, D. (1998), A 16S ribosomal DNA typing for identification of pathogens in patients with bacterial keratitis J. Clin. Microbial. 36: 2505-2209 In: Kaisu, R.J. Simo, N. Jari, J. et al (2000), Direct Amplification of rRKNA genes in Diagnosis of bacterial infections. Journal of Clinical Microbiology 38 (1): 32-39.

Kotilainean, P; Jalava, J. Meurman, O., Lehtonen, O.P, Rintala, E.; Seppala, E.P; Eerola, E. and Nikkari, S. (1998). Diagnosis of Meningococcal local meningititis by broad range bacterial PCR with cerebrospinal fluid. J. Clin. Microbial. 36:2205-2209. In Kaisu, R.J., Simo, N., Jari, J. et al (2000). Direct amplification of rRNA genes In: Diagnosis of bacterial infections. Journal of clinical Microbiology 38(1) 21-29.

Kupila, L., Rantakokko-Jalava, K. Jalava, J. et al (2003), Aetiological Diagnosis of Brain Abscessess ad Spinal Infections: application of Broad Range Bacterial Polymerase Chain Reaction Analysis. Journal of Neurology, Neurosurgery and psychiatry 74: 728 - 733

Lena, L.B., Christina, W.O. Teresa, L., John T. et al (1998). Evaluation of PCR for Diagnosis of Bordetella pertusis and Bordetella parapertusis Infections. Journal of clinical microbiology 36 (3): 326-382.

Marek, G., Malgorzata, P.T., Maria, K.M., Ewa, K.J et al (2006) Application of Polymerase chain reaction (PCR) in the diagnosis of endophthalmitis. In: https://www.researchgate.net/publication/65 13880_Application_of_polymerase_chain...

Margall, C., Majo, Moreno., M., Laturreotin C. et al (2002) use of Universal PCR on Cerebrospinal fluid to Diagnose Bacterial Meningitis in Culture-Negative Patient. European Journal of Clinical Microbiology and Infectious Diseases. 21 (2): 67-69.

Mullis, K.B., and Falcoona, F.A. (1987). Specific Synthesis of Polymerase Catalyzed Chain reaction. Methods Enzymol. 155: 335-350. In: Kaisu, R.J; Simo, N., Jari, J. et al (2000). Direct amplification of rRNA genes in Diagnosis of bacterial infection. Journal of clinical microbiology 38(1): 32-39.

Noordhock, G.T., Kolk, A.H., Gjune, G., Cathy, D. Dale, JW et al (1994). Sensitivity and specificity of PCR for detection of tuberculosis: A Blind Comparison study among seven laboratories. Journal of Clinical Microbiology 32:2770-284. 
Post, J.C., Preston, R.A. Aul J.J., Larkins-Peltigrew, M. (1995). Molecular analysis of bacterial pathogens in Otitis media with effusion. JAMA 273: 1598-604 In: Chul-won, $\mathrm{P}$; Jang-Hee, $\mathrm{H}$. et al (2004). Detection rates of Bacteria in chronic otitis media with effusion in children Journal of Korean Medical Sciences 19: 735738.

Rabinow, and Paul (1996). Making PCR: A Story of Biotechnology. Chicago: University of Chicago press ISBN 0-226-70146-8.

Rayner, M.G., Zhang, Y., Gorry, M.C. Chen, Y., Post, J.C. and Ehrlich, G.D. (1998) Evidence of bacterial metabolic activity in culture-negative otitis media with effusion In: Chuolwon, P., Jang-Hee, H., Jin, Heyeok J. et al (2004) Detection rates of Bacteria in chronic Otitis Media with effusion in children. Journal of Korean Medical Sciences 19:735-738.

Reznikov, M., Blackmore, T.K., Finlay-Jones, J.J. and Gordon, O.L. (1995). Comparison of nasopharyngeal aspirates and throat swab specimens in a polymerase chain reaction based test for Mycoplasma pneumoniae. European Journal Clinical Microbiology and infectious diseases. 14: 58-61.

Rhaods, R.E., Rychlik, W. and Spencer, W.J. (1990): "Optimization of the annealing temperature for DNA amplification in vitro". Nucleic Acids Research 18:6409-6412. In: http/www.pubmedcentral.nih.gov/articlerend ev.fcgi?tool=opubmed\&pubmedid=2243783.

Rowland, B. and Frey, R.J. (2005). Scarlet Fever In: http://www.ncbi.nim.goventrez/query.fcgi?

Santos, L.C (2007). Bacterial meningitis in an Urban Area. Etiologic Study and Prognostic Factors Infection. In: European Journal of Clinical Microbiology and Infectious Diseases Vol.21 (2).

Saiki, R.K., Gelfand, D.H., Stoffels, E. et al (1988). "Primer-directed enzymatic amplification of DNA with a thermastable DNA polymerase". Science 239: 487-91. In: http:/sunsite.berkeley.edu/cgibinebind2html/ PCR/009

Senturia, B.H., Gessert, C.F., Carr, C.D. and Baumann, E.S. (1958). Studies Concerned with
Tubotympanitis. Ann. otol Rhino laryngol 67:440-67.

Skakni, L., Sardet, A. and Just, J. (1992). Detection of Mycoplasma pneumoniae in clinical samples from pediatric patients by polymerase chain reaction Journal of Clinical Microbiology 30:2638-43.

Sudre, P., Tendam, G. and Kochi, A. (1992). Tuberculosis: A global review of the situation today. Bull WHO 1992., 70: 149-15 In: http://www.indianpediatrics.net/april2000/ap ril-375-382.

Sunil, K.J., Nasir, M.G.G., Kunal, K.L. and Sarin, N.P. (2000). Polymerase chain reaction in the diagnosis of tuberculosis. In: http://www.indianpediatrics.net/april2000/ap ril-375-382.

Tan, M.F. Nig, W.C., Chan, B.H. and Tan, W.C. (1997).Comparative usefulness of Pen in the detection of Mycobacterium tuberculosis in different clinical specimens. Journal of microbiology 46: 164-189. In: Sunil, K.J., Nasir, M.N.G., Kunal, K.L and Sarin, N.P. (2000). Polymerase chain reaction in the diagnosis of tuberculosis. In: http://www. indianpediatrics.netapril2000/apri 1-375-382.

Welinderolsson, C. (2007) Comparison of Broad Range Bacterial PCR and culture of cerebrospinal fluid for diagnosis of community acquired bacterial Meningitis. In: European Journal of Clinical Microbiology and Infectious Diseases Vol. 21(1): 67-69. 